International Journal of Applied Economics, Finance and Accounting

ISSN 2577-767X

Vol. 4, No. 1, pp. 22-27

2019

DOI: $10.33094 / 8.2017 .2019 .41 .22 .27$

(C) 2019 by the authors; licensee Online Academic Press, USA

\title{
Juxtaposing Government Borrowings and the Nigerian Financial Environment
}

'Department of Accounting, Crawford University, Igbesa, Ogun State Nigeria Emailiomorogbece@yahoo.com

${ }^{2}$ Department of Accountancy, Ogun State Institute of Technology, Igbesa, Ogun State Nigeria

Licensed:

This work is licensed under a Creative Commons Attribution 4.o License.

Keywords:

Government

Borrowings

Financial-environment

Domestic- debt

External-debt.

\begin{abstract}
Government borrowing is desirable when it propels economic growth. Banks are the key players in Nigeria financial environments mobilising funds for the government via domestic and external debts. This study examined how government borrowings have impacted on the Nigerian financial environment. The study is archival, utilising data from the Central bank of Nigeria (CBN) and Nigeria Bureau for Statistics (NBS) bulletins. A Time Series data of 36 years-period (1981-2016), were collected. Multiple regression tool with Ordinary Least Squares $(O L S)$ method of estimation of parameters was used to analyse the data. The results showed a linear relationship between money supply and foreign and domestic debts ( R2=0.984) with foreign and domestic debts explaining 98\% of the variation in money supply; and correlation value indicating a very strong positive significant relationship between the interest rate and domestic and foreign debts $(r=0.992 ; p<0.05)$.Thus the study among others recommended servicing of debts on a persistent basis, so as to avoid recapitalization of arrears which may mount pressure on the nation's debt stock.
\end{abstract}

Funding: This study received no specific financial support.

Competing Interests: The authors declare that they have no competing interests.

\section{Introduction}

In the recent past, it has been observed that the Nigeria economy has been mauled by public debt as reflected in the consistent deficit budget of the nation. Borrowing has often been resorted into, due to the dwindling revenue and increasing expansion of government expenditures.

Government borrowings are in the form of domestic debts sourced internally by issuing securities, bonds, federal government development stocks, treasury bills and certificates; while external debts or foreign debts, are generated from institutions such as World Bank, and the International Monetary Fund. The Nigerian government has acquired a large amount of loan, often at high-interest rates over the past two decades with the bid of using the loans to promote faster route for development through higher investment, faster growth and poverty improvement, yet there has been constant economic growth. This situation, however, negates the Neo-classical theory which postulates that an economy will not suffer from macroeconomic instability, where debt borrowed is optimally utilized as debt has a direct effect on economic growth. The outcome of the borrowed fund is dependent on the level of investment and the ability to maintain a good capacity to service such debt. This is vital as debt repayment and debt servicing have a negative effect on economic growth (Izedonmi \& Ilaboya, 2012).

The bottom line is that the way and manner debts are managed to determine the effect on the economy. It is worthy to state that, despite the government unfaltering effort in managing external debt, several measures have been embarked on such as, debt rescheduling, debt conversion, debt equity, debt forgiveness and cancellation, Nigeria's external and internal debts outstanding continue to increase at an alarming rate, the nation also benefited from debt forgiveness of $60 \%$ (US $\$ 18$ billion) of the US $\$ 30.85$ billion debt owed at Paris Club in 2006. The increase in debt which seemed unattended to has become alarming considering the threats it poses to the financial situation and environment within the nation and the economy as a whole. While looking at the economy of the nation, the effect of government borrowings bothers on economic-variables such as economic growth, prices (Inflation), investment and interest rates, all of which characterise the financial 
environment of a nation. The government is expected to fashion a way through which debt position would be managed effectively so that, the level of debt will not be counterproductive.

Several studies conducted in this direction, analyse the relationship between government borrowing and economic growth. In Nigeria, many studies have focused on international debt, some on domestic debt and others on public debt generally, but the impact of government borrowing and public debt on the Nigeria financial environment (which serves as financial intermediaries in mobilizing funds/loans for the government from individuals/organisations) has not been dealt with extensively. This study objective is therefore to examine the impact of government borrowing on the Nigeria financial environment. The financial environment is represented by the money supply and interest rate.

The impact of government borrowing money supply and bank Interest rate in Nigeria was hypothesised and tested: $\mathrm{H}_{01}$ : Government borrowing has no significant impact on money supply; $\mathrm{H}_{02}$ : There is no significant impact of government borrowing on the bank interest rate.

This paper is segmented into four sections; closely following the introduction is a literature review, section three is the methods, section four is results, and discussion of findings while section five is conclusion and recommendations

\section{Literatures Review}

The Concept of Public Debt and Nigerian Financial Environment

Public debt arises out of government borrowing via the treasury from banks, business organisation, and individuals via the process of buying and selling of Treasury securities through the open market operations. Active financial participants and intermediaries in the financial environment dealing with government securities both in the primary and secondary markets are financial institutions such as Insurance companies, pension, and social security funds; commercial, savings, merchant banks and the Central bank. The Nigeria financial system includes; financial institutions including the regulatory and supervisory authorities, development finance institutions (Urban Development, Nigerian Agricultural and Rural Cooperatives bank), financial markets (money and capital markets), and other finance institutions (finance companies, Insurance companies, pension funds, primary Mortgage Institutions and Bureau de change,) among others. The key players in the Nigeria financial sectors/determinants of financial environment comprises Deposit Money Banks (DMB), Finance companies, Insurance Companies, Nigeria Security and Exchange Commission (SEC), Nigeria Deposit Insurance Corporation NDIC), Central Bank of Nigeria (CBN), Debt Management Office (DMO), Primary Mortgage Institutions, Nigeria Agricultural Cooperative Bank of Industry (BOI), Rural Development Bank (NACRDB) and Nigerian Export-Import Bank (NEXIM).

Government borrowing is simply the amount raised by the government of any nation from all sources to complement available resources with a view to discharging her responsibility to the citizens. It usually arises because of the constant need for government to augment her finances, and to make capital available towards sustainable economic activities within the nation. Countries at their early developmental stages borrow to boost their growth level and aggrandise their finance due to the prevalence of small capital stocks that are likely, to have investment opportunities with higher rates of returns than that of their counterparts in developed countries (Egbetunde, 2012). Hence, public debt provides the additional investment needed for attaining the desired economic growth and serves as a means of bridging the savings-investment gap. It, therefore, implies that countries borrow because they are unable to generate enough finance internally to fund economic activities and meet with social obligations including the provision of infrastructures.

Since the act of borrowing creates debts, it is therefore imperative for this study not to examine government borrowing in isolation of public debt. Udoka and Ogege (2012) said government incurred debts to fund domestic investments by borrowing from domestic and international markets. The summation of all claims held against the government by private and foreigners, whether interest-bearing or not (and including bank held debt and government currency, if any); less any claims held by the government against the private sector and foreigners, are referred to as national debt.

Kamundia (2015) defined public debt as the aggregate amount that the government owes to its creditors, which is characterised as either internal debt or external debt. Ogbeifin (2007), in Olanrewaju, Abubakar, and Abu (2015) defined Nigeria's external debt as that portion of a nation's debt that is sourced from foreign sources such as government, financial institutions or foreign corporations. CBN reports that Nigeria has contracted a number of debt obligations from external sources, some of which are Paris Club of creditors, London Club of creditors, Ford Motors, Multilateral Creditors, Promissory Note Creditors, Bilateral and Private Sector Creditors. The Debt Management Office Nigeria Report (2018) reported that the country's external debt rose from $\$ 10.32$ bn on June 30, 2015 to $\$ 22.08$ bn as of June 30 2018, meaning that the external debt commitment of Nigeria has grown by 114.05 percent in the last three years. This increase according to DMO was associated with commercial foreign loans, which stood at $\$ 1.5 \mathrm{bn}$ as of June 30, 2015, had risen to $\$ 8.8 \mathrm{bn}$ as of June 30, 2018.

On the other hand, internal borrowings also known as domestic debts are debts instrument dominated in local currency usually issued by the Federal Government and denominated in local currency (Charles, 2012). These are government borrowings within the country, such as local citizens and organisation. Government at the state or local level can also issue debt instrument, consisting of Nigerian treasury bills, treasury 
certificates treasury bonds, government development stock and revenue bonds. The DMO also reported, that domestic debt, stood at N12.15tn in June 2018, and the total debt as N22.38 trillion (\$73.21 billion) as at June 30, 2018. The Central Bank of Nigeria (CBN), a financial adviser and banker to the Federal Government is saddled with managing the domestic public debt in Nigeria situation.

Several extensive studies acknowledged that government borrowing impacts the economic growth of a nation, and invariably its financial environment through various channels. The financial environments are the financial participants or intermediaries that operate in the financial sector in the economy.

\subsection{Theoretical Consideration}

The understanding of the impact of government borrowing emanates from the exploration of a number of theories that attempt to explain the essence and justification behind the constant need by government to borrow which arises from the recognised role of capital in the developmental process of a nation. Such theories include the dual gap theory, debt-cum-growth model, Neo-classical (Keynesian) theory, Profligacy theory and threshold school of thought. However, for the purpose of this study, the theory to be examined is the Dual-gap theory.

The Dual-Gap Theory emphasised that sustainable economic growth requires a given level of savings and investment and in a case where it is not sufficient, it results in external borrowing, herein lays the basis for the dual-gap analysis. This theory postulates that investment is a function of savings and for development to occur in an economy, it requires investment. Therefore, an investment which requires domestic savings is not sufficient enough to ensure that development takes place. The dual-gap framework is coined from a national income accounting identity which states that excess investment expenditure over domestic savings is equivalent to the surplus of imports over exports.

This study relied on the dual gap theory because it is derived from national income accounting and the level of savings and investment in any economy are greatly determined by money supply, interest and inflation rate, which the dual-gap theory sets a basis for.

\subsection{Empirical Review}

Oshadami (2006), cited in Adofu and Abula (2010) concluded in their study that the growth of domestic debt has negatively affected the growth of Nigeria's economy. However, Egbetunde (2012) in his study found that public debt and economic growth are moving in the same direction; though, domestic debt promotes the economy better than external debt. It is even better for the economy to source funds internally, so that when the principal and interest on the loan are paid installmentally, the funds will still be revolving within the economy. Ebi, Abu, and Clement (2013) used the error correction model to investigate the relative potency of external and domestic debt on economic performance in Nigeria. Economic growth was determined by external debt, domestic debt, gross domestic investment (GDI), exchange rates and inflation while gross domestic investment was influenced by external debt, domestic debt, and interest rates. Both domestic and external debts were found to have a positive effect on economic performance but external debt had a significant impact, the domestic debt had an insignificant impact. The impact of external debt on GDI was negative and insignificant while the impact of domestic debt on GDI was positive and significant. The study concluded that external debt and not domestic debt has a crowding out effect on the level of investments in Nigeria. Olanrewaju et al. (2015) examined the effect of government debt on economic growth in Nigeria between 1986 and 2013, using the ordinary least square method, the study revealed that the impact of government debt on economic growth over the period under review was insignificant External debt which has been enormous over the years contributed minimally to the real gross domestic product. Abula and Ben (2016) in their study, concluded that external debt of Nigeria has not been instrumental in enhancing the development of Nigeria's economy and an increase in the level of debt servicing to the various creditors of the economy would reduce the level of economic growth and development in Nigeria.

Observing the areas covered by these studies, this research focused on public borrowing viz-a-viz money supply and interest rate referred here as the financial environment.

\section{Research Method}

This study is a quasi-experimental study design based on archival data in examining government borrowing on the financial environment. The study obtained data from the Central bank of Nigeria $(\mathrm{CBN})$ and the Nigeria Bureau for Statistics (NBS) bulletins. A Time Series data of 36 years-period (1981-2016), were collected. Multiple regression tool with Ordinary Least Squares (OLS) method of estimation of parameters was used to analyse the data.

3.1. Model Specification

Multiple regression models were fitted to analyse the variables as shown below;

$$
\begin{aligned}
\mathrm{MS} & =\beta_{0}+\beta_{1} \mathrm{ED}+\beta_{2} \mathrm{DD}+\epsilon \ldots \ldots \ldots \ldots \ldots \ldots \ldots \ldots \ldots \ldots \ldots \ldots \ldots \ldots \ldots \ldots \ldots \ldots \ldots \ldots \ldots \ldots \\
\mathrm{BIR} & =\beta_{0}+\beta_{1} \mathrm{ED}+\beta_{2} \mathrm{DD}+\epsilon \ldots \ldots \ldots \ldots \ldots \ldots \ldots \ldots \ldots \ldots
\end{aligned}
$$

Where: 
$\mathrm{ED}=$ the External Debt

$\mathrm{DD}=$ the Domestic Debt

$\mathrm{BIR}=$ Banks Interest Rate

MS= Money Supply

$\epsilon=$ Error Term

$\beta_{0}, \beta_{1}$ and $\beta_{2}$ are parameters to be estimated

\section{Results and Discussion of Findings}

4.1. Test of Hypothesis One

$\mathrm{H}_{01}$ : Government borrowing has no significant impact on money supply

To measure the relationship between individual independent (Domestic debt and foreign debts) and dependent variable (Money supply), a Regression analysis was conducted. The regression analysis was of the form:

$\mathbf{Y}=\boldsymbol{\beta}_{0}+\boldsymbol{\beta}_{1} \mathbf{X}_{1}+\boldsymbol{\beta}_{2} \mathbf{X}_{2}+\mathbf{e}$

Whereby $\mathrm{Y}$ is Money supply, $\mathrm{X}_{1}$ is the domestic debt, $\mathrm{X}_{2}$ is the foreign debt, $\beta_{0}$ represents the regression constant, while $\beta_{1}$ and $\beta_{2}$ represent the regression coefficients and $\varepsilon$ represent the model's error term. The relationship's strength were illustrated by the model summary below.

Table-1. Impact of Government Borrowing on Money supply.

Model Summary

\begin{tabular}{c|c|c|c|c}
\hline Model & $\mathbf{R}$ & R Square & Adjusted R Square & Std. Error of the Estimate \\
\hline \multicolumn{2}{|c|}{$0.992^{\text {a }}$} & 0.984 & 0.983 & 819.55166 \\
\hline \multicolumn{2}{rl}{ Note: a. Predictors: (Constant), domestic debts, foreign debts. }
\end{tabular}

The coefficient of correlation in Table 1 was 0.992 whereas the value of adjusted R-square was 0.983. This implied that there is a very strong positive correlation existing between money supply and the foreign and domestic debts (two independents variables). The adjusted $\mathrm{R}^{2}$ of 0.983 showed that foreign and domestic debts explained about $98.3 \%$ variation of money supply in Nigeria.

4.2. Analysis of Variance

The ANOVA results presented in Table 2 showed that the model is statistically significant $(\mathrm{p}<0.05$; with a high F-ratio explaining the goodness of fit of the model.

ANOVA $^{\mathrm{a}}$

Table-2. Impact of Government Borrowing on Money supply.

\begin{tabular}{c|c|c|c|c|c|c}
\hline \multicolumn{2}{c|}{ Model } & Sum of Squares & Df & Mean Square & F & Sig. \\
\hline \multirow{3}{*}{1} & Regression & 1395240126.646 & 2 & 697620063.323 & 1038.643 & $.000^{\mathrm{b}}$ \\
\cline { 2 - 7 } & Residual & 22164942.312 & 33 & 671664.919 & & \\
\cline { 2 - 7 } & Total & 1417405068.958 & 35 & & & \\
\hline
\end{tabular}

b. Predictors: (Constant), domestic debts, foreign debts.

Coefficients $^{\mathrm{a}}$

Table-3. Impact of Government Borrowing on Money supply.

\begin{tabular}{l|c|c|c|c|c|c}
\hline \multirow{2}{*}{ Model } & \multicolumn{2}{c|}{ Unstandardized Coefficients } & Standardized Coefficients & \multirow{2}{*}{ T } & Sig. \\
\cline { 3 - 6 } \multicolumn{2}{c|}{1} & B & Std. Error & Beta & .773 & .445 \\
\hline \multirow{2}{*}{1} & Constant) & 148.964 & 192.618 & & -3.387 & .002 \\
\cline { 2 - 6 } & FOREIGN DEBTS & -.354 & .105 & -.077 & 44.335 & .000 \\
\cline { 2 - 5 } & $\begin{array}{c}\text { DOMESTIC } \\
\text { DEBTS }\end{array}$ & 2.212 & .050 & 1.013 &
\end{tabular}

From the coefficient in Table 3, it shows that the most significant factor in influencing money supply was domestic debt followed by foreign debts $(\mathrm{p} \leq 0.01)$.

4.3. Test of Hypothesis Two

$\mathrm{H}_{02}$ : There is no significant impact of government borrowing on bank interest rate

To measure the relationship between individual independent (Domestic debt and foreign debts) and dependent variable (Interest rate) Regression analysis was conducted. The regression analysis was of the form: $\mathrm{Y}=\beta_{0}+\beta_{1} \mathrm{X}_{1}+\beta_{2} \mathrm{X}_{2}+\mathrm{e}$ 
Whereby $\mathrm{Y}$ is Interest rate, $\mathrm{X}_{1}$ is the domestic debt, $\mathrm{X}_{2}$ is the foreign debt, $\beta_{0}$ represents the regression constant, while $\beta_{1}$ and $\beta_{2}$ represent the regression coefficients and $\varepsilon$ represent the model's error term. The relationship's strength were illustrated by the model summary below.

Table-4. Impact of Government Borrowing on Bank Interest Rate. Model Summary

\begin{tabular}{c|c|c|c|c}
\hline Model & $\mathbf{R}$ & R Square & Adjusted R Square & Std. Error of the Estimate \\
\hline 1 & $.459^{\text {a }}$ & .211 & .163 & 3.85953 \\
\hline
\end{tabular}

The coefficient of correlation in Table 4 was 0.459 whereas the value of adjusted R-square was 0.163 . This implied that there is a moderate positive correlation between interest rate and domestic and foreign debts (the two independents variables). The adjusted $\mathrm{R}^{2} 0.163$ showed that domestic and foreign debts explained about $16.3 \%$ of variation in interest rate.

\subsection{Analysis of Variance}

The Analysis of Variance (ANOVA), results presented in Table 5 showed that the model is fairly statistically significant $(\mathrm{p}<0.05$; with a very low F-ratio explaining low goodness of fit of the model.

Table-5. Impact of Government Borrowing on Bank Interest Rate.

\begin{tabular}{|c|c|c|c|c|c|c|}
\hline \multicolumn{7}{|c|}{ ANOVA ${ }^{\mathrm{a}}$} \\
\hline & Iodel & Sum of Squares & Df & Mean Square & $\mathbf{F}$ & Sig. \\
\hline \multirow[t]{3}{*}{1} & Regression & 131.509 & 2 & 65.755 & 4.414 & $.020^{\mathrm{b}}$ \\
\hline & Residual & 491.567 & 33 & 14.896 & & \\
\hline & Total & 623.076 & 35 & & & \\
\hline
\end{tabular}

b. Predictors: (Constant), domestic debts, foreign debts.

Coefficients $^{\mathrm{a}}$

Table-6. Impact of Government Borrowing on Bank Interest Rate.

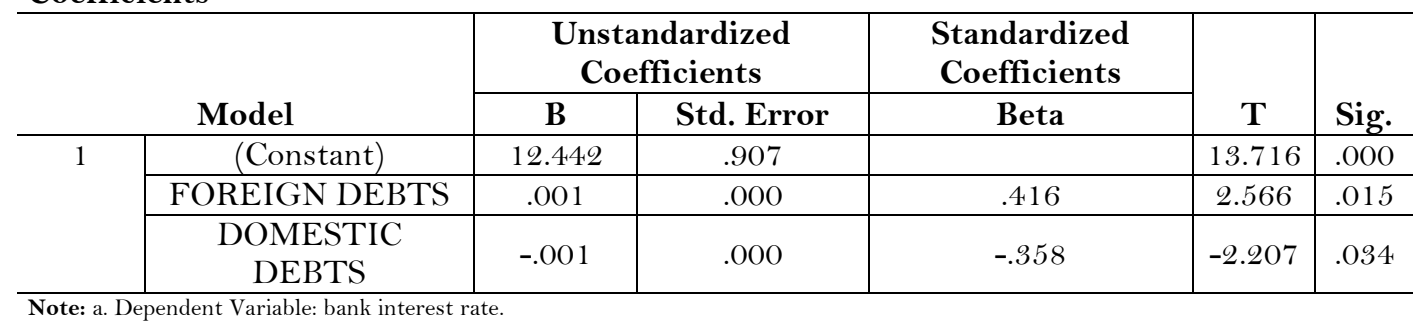

Table 6 on coefficient of the model, it showed that a one unit increase in foreign debt leads to 0.001 interest rate increase and one unit increase in domestic debt leads to -.001 decrease in the interest rate. This meant that the most significant factor in influencing interest rate was foreign debt $(\mathrm{P} \leq 0.05)$.

\section{Conclusion and Recommendation}

This study has empirically shown that government borrowings had an impact on the financial environment of Nigeria. From the analysis of data, it reveals that government borrowing has a significant effect on the Nigerian financial environment. Evidence from this study, also show that government borrowing, especially, domestic debt has a direct and significant effect on the rate of money supply in the nation. A rise in the level of domestic debts will give rise to an increase in the money supply. There is an overwhelming proof from the results of this work that the Interest rate is directly affected by foreign debt as every debt received from external sources technically increases the amount of bank interest rate. Domestic debts on the other hand, had almost no effect on the interest rate.

Even though government borrowings by developing countries are expected to complement their low capital stock given their high marginal returns on capital, however, this is not the case in Nigeria. Government borrowings have not been able to produce any desired result on the economy due to corruption and fiscal indiscipline. The heavy debt burden by Nigeria government has always resulted into great pressure on the budget and deficit financing as habitude aid, the multiplier effects are what the nation's economic condition is experiencing presently, in terms of; poverty, unemployment, devalued rate of Naira and low purchasing power.

The following recommendations are therefore suggested;

The Nigerian government should try as much as possible to raise her borrowings from sources within the country (internal borrowing), so as to limit the foreign debt effect arising from foreign exchange risk since 
repayment (interest and principal) will be in foreign currency which often impact on the interest rate. In addition, the internal borrowing is also used to reduce the flow of money in circulation, as a monetary policy tool;

The Nation should ensure a prudent debt management policy that would ensure that borrowings are only made to finance top priority projects;

Domestic borrowings affect the rate of investments within the country. The government should, therefore, try to uphold preparation of surplus or balanced fiscal policy so as to avoid the need to borrow and

The government should use funds judiciously for the purpose it is meant for. Avoiding misappropriation, diversion, and mismanagement so that deficits that lead to borrowings will as well be avoided.

\section{References}

Abula, M., \& Ben, D. M. (2016). The impact of public debt on economic development of Nigeria. Asian Study Journal of Arts and Social Sciences, 1(1), 1-16.

Adofu, I., \& Abula, M. (2010). Domestic debt and the Nigeria economy. Journal of Economic Theory, 2(1), 22-26.

Charles, O. (2012). Domestic debts and the growth of Nigeria economy. Journals of Finance and Accounting, 3(5), 45-56.

Debt Management Office Nigeria Report. (2018). Total public debt. Retrieved from https://www.dmo.gov.ng. [Accessed, 13th December 2018].

Ebi, B. O., Abu, M., \& Clement, O. D. (2013). The relative potency of external and domestic debts on economic performance in Nigeria. European Journal of Humanities and Social Sciences, 27(1), 1415-1429.

Egbetunde, T. (2012). Public debt and economic growth in Nigeria: Evidence from granger casuality. American Journal of Economics, 2(6), 101-106.

Izedonmi, F. I., \& Ilaboya, O. J. (2012). Public debt-growth dynamics: The Nigeria experience. Journal of Research in National Development, $10(3)$, 252-260.

Kamundia, S. W. (2015). The effects of public debt on private investments and economic growth in Kenya (1980-2000). Dissertation Submitted to Department of Kenyatta University. Retrieved from http://ir-library.ku.ac.ke. [Accessed,13th February, 2018].

Olanrewaju, M. H., Abubakar, S., \& Abu, J. (2015). Implications of external debts on the Nigeria economy: Analysis of the dual gap theory. Journals of Economics and Sustainable Development, 6(13), 238-249.

Udoka, C. O., \& Ogege, S. (2012). Public debt and the crisis of development in Nigeria econometric investigation. Asian Journal of Finance and Accounting, 4(2), 231-243. 